CURRENT RESEARCH JOURNAL OF PHILOLOGICAL SCIENCES

(ISSN -2767-3758)

VOLUME 03 ISSUE 01 Pages: 64-72

SJIF IMPACT FACTOR (2021: 5. 823)

OCLC - 1242423883 METADATA IF - 6.925

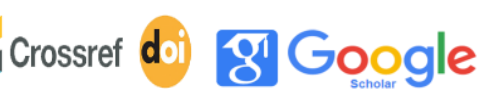

10.

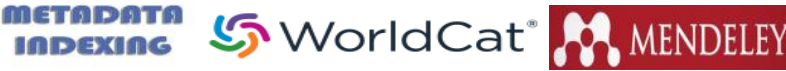

Publisher: Master Journals

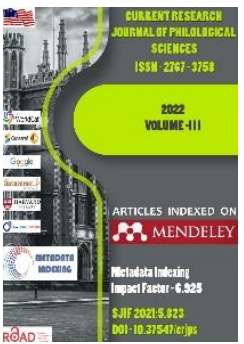

Journal Website: https://masterjournals. com/index.php/crjps

Copyright: Original content from this work may be used under the terms of the creative commons attributes 4.0 licence.
Research Article

\section{LINGUISTIC UNITS THAT FORM THE BASIS OF SOCIAL ADAPTATION IN JADID DRAMAS}

\author{
Submission Date: January 08, 2022, Accepted Date: January 20, 2022, \\ Published Date: January 30, 2022 \\ Crossref doi: https://doi.org/10.37547/philological-crjps-03-01-11
}

Doniyorbek Rustamov

Tashkent State University of Uzbek Language and Literature named after Alisher Navoi, Uzbekistan

\title{
ABSTRACT
}

The article analyzes the linguistic means by which the Jadid dramas form social adaptations in the speech of the protagonists, and identifies the specific semantic aspects of the grammatical means. In particular, it was noted that synonyms of adverbs, adverbs, pronouns, and adverbs have a special place, including the specific functions of pronouns.

\section{KEYWORDS}

Linguistic units, social adaptation, speech forms, monologue, dialogue, phrases, auxiliary words, downloads, pragmatic approach.

\section{INTRODUCTION}

In recent years, research on text analysis in Uzbek linguistics has increased, and it was very necessary. In Uzbek linguistics, special attention is paid to linguopoetic, pragmatic, sociopragmatic analysis. In particular, Sh. Safarov "Pragmalinguistics", M. Hakimov pragmatic interpretation of the text in Uzbek,
Sh. A.Shomaksudov The language of Muqimi's satires, I.Kuchkartoev's phraseological innovation of Abdulla Qahhor, B.Yuldashev "Language and Style of Said Ahmads writings", E.Abdiev "The language and style of drama by Kamil Yashin”, T.Choriev Sadriddin Language and style of publicist works (vocabulary and 
CURRENT RESEARCH JOURNAL OF PHILOLOGICAL SCIENCES

(ISSN -2767-3758)

VOLUME 03 ISSUE 01 Pages: 64-72

SJIF IMPACT FACTOR (2021: 5. 823)

OCLC - 1242423883 METADATA IF - 6.925

phraseology), S.U.Boymirzaeva Linguistic-stylistic study of Oybek's prose; Lexical-spiritual and methodological features of letters in the novel "Last Days" by Chorieva Z.Abdulla Qodiri; Linguistic features of R.Normurodov Shukur Kholmirzaev's works, research such as $M$. Kochkarova "Thematic classification of Abdulla Qahhor's literary-critical journalism" is important in this regard.

\section{LITERATURE REVIEW}

In particular, I.Mirzaev's Problem lingvopoeticheskoy interperetatsii stixotvornogo text, N.Mahmudov on the linguopoetics of Abdulla Qahhor's stories, G.Muhammadjanova Linguopoetic study of Uzbek poetry in the late 80 s and early 90s, Z.Khamidov M.Yuldashev Cholpon's artistic language skills, Sh.Tashkhodjaeva's "Linguopoetics of Erkin Azam's works", V.Kholmatova's "On the interpretation of the concept of pragmatics" the general knowledge of language owners about the object of speech is formed in relation to the language knowledge and skills of speech participants [1, p. 94]. M. Hakimov notes that in general, the following components are involved in the speech act: speaker, listener, object of speech - factual material and speech situation. M. Kurbanova emphasizes that the general language knowledge and language skills of the participants should be included in the list of components necessary for the implementation of the speech act [2, pp. 96-97].

But there is little research devoted to the analysis of dramatic works. In particular, there has been little scientific research on the sociopragmatic analysis of the linguistic means used in the text of dramas. The social characterization of linguistic means in the speech of drama protagonists needs to be systematically studied in monograph form. In this regard, Sh. Rahmatullaev has comments that complement the above: "Grammatical meaning is usually an abstract concept, expressed in addition to the lexical meaning of the word, along with other similar concepts, that define the function and place of the word in the sentence construction system. For example, the conjugation forms show the syntactic connection of the horse with other words, ensuring that it comes in the functions of possessive, complementary, determinative, case" [3, p. 399]. ZIYoLI (jiddiyat ila). Boy afandi! Men sizga dedimki, millatga keraklik ilmlar to'g'risida so'zlamoqchiman, ammo siz meni(ng) so'zimii eshitmoqg'a xohlamayturg‘ong'a o'xshaysiz. Ikkinchi daf'a aytamanki, quloq bering va bu so'zlar sizni(ng) va millatni(ng) naf'idur. [4, p. 69] (Behbudi, Padarkush, act 1.)

\section{ANALYSIS AND RESULTS}

Indeed, the development of language is directly related to the thinking and creativity of a nation's poets or writers and scholars. When researchers work on the theoretical foundations of tin, creators are able to create new ways of expressing it, as well as some tools, while using it. Each artist uses language in his or her own way. In dramatic works, there are other aspects of language. Mahmudhoja Behbudi has his own approach. To find out the practical expression of this, it is necessary to analyze the text of the dramas "Padarkush", "Abulfayzkhan", “The Unhappy Groom". The drama "Padarkush" has the following locations:

\section{ZIYOLI. Assalomu alaykum.}

BOY (karaxtlik ila). Vaalaykum assalom, Xayrullo, kursi keltur. Bu kishi yerga o'Iturolmaydur (kelturar, ziyoli o'Iturub, papirus chekar).

ZIYOLI. Janob boy, sizni kayfsiz ko'raman, mumkinmi sababini bilsam? 
CURRENT RESEARCH JOURNAL OF PHILOLOGICAL SCIENCES

(ISSN -2767-3758)

VOLUME 03 ISSUE 01 Pages: 64-72

SJIF IMPACT FACTOR (2021: 5. 823)

OCLC - 1242423883 METADATA IF - 6.925

Crossref
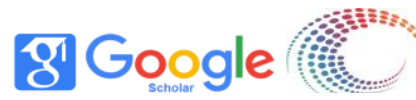
metapata (5) WorldCat I $^{\circ}$ MENDELEY

Publisher: Master Journals

BOY. Bir mullo kelib edi, o'g'lingni o'qutmaysan deb juda jonimni oldi, quvlagandek qilib zo'rg'a qutuldim, faqat mushtlashmadik.

ZIYOLI. Ah-ha, qiziq va interesniy hodisa emish (odamlarga qarab), bu shaharda boylarga amri ma'ruf qilaturg'on mulla bor ekan, Xudoga shukur. Ul janobi haqqoniy domullani topib, ziyorat qilmoq kerak. Boy afandi, sizga malol kelmasun, ushbu to'g'ridan men ham sizga qachonlardir bir necha so'z aytmoqchi edim. Va ammo soati ushbu daqiqaga mavquf ekan, endi sizdan iltimos qilamanki, bir necha daqiqa menga quloq bersangizki, ilm nafi to'g'risida so'zlayin.

First of all, the most important feature of Behbudi's use of language is his ability to use simple forms of speech effectively. Some performers use complex long sentences with a few long follow-up sentences in a work of art, resulting in confusion. The use of complex conjunctions in drama reduces the impact of speech. In this sense, the author can use simple sentences in dialogues effectively and purposefully:

//Pivaxona manzarasi: boyvachcha ila uch nafar o'Iturarlar.

TANGRIQUL. Bu oqshom, bilmayman, nima uchun ichkilik meni tishlamaydur: Namozi digardan beri bir dyujina shishani bo'shatdim. Dayusni pivosi qulog'imni qizitmadi. To'Idir, ichaylik (Nor qadahlarni to'Idirar).

HAMMASI. Toshmurod boyvachchani salomatligiga ura! Ura! Ura! (icharlar).

DAVLAT. Jo'ralar. Manuvni ichdim, endi yodimga Lizajon tushdi. O, Lizajon!

HAMMASI. Oh, Lizajon, voh, Lizajon, qaydasan?

NOR. Zolim falak firoqig'a kuydirdi mani; billohki, kelmasa, bo'miydi.
DAVLAT. Bu dodu bedod ila hech nima bo'Imas. Xo'jayinni chaqirarmiz, otam o'ldi bazmi qilarmiz. (Behbudi, Padarkush, act 2.)

In the text, the work also retains some dialectal elements in the speech of the protagonists in order to show the original habitat:

// TANGRIQUL. Jo'ralar. Sizlardan yashiraturg'on so'zimiz yo'q. To'g'risini desam, manuni ichdim, qulog'im qizig‘an, sen Liza deding, endi o'zim shunda bo'Isam-da, hushim Lizaga, to Lizani kelturmasang, mani gapirturolmaysan. Ammo gap kelturganingga, Davlat zo'r!

DAVLAT. G'am yema, muddaong Liza bo'Isa, shul zamon yoningga ko'rarsan, kelmasami? Boshini olarman.

NOR. Boyvachcha! Barishnaga tobingiz bormi?

TOShMUROD. Mayli, odam yuboringlar, bazm qilsun.

// (Behbudi, Padarkush, act 2.)

In literary language, there are places in fiction where the directional conjunction (ga) is used instead of the place conjunction (da), but this is a methodological error. The author deliberately uses the dialectal pronunciation of the agreements as required by the situation.

In the following text, the author shows the addressee the inner nature of the protagonist in this situation. Behbudi often uses simple sentences with one head. This is in line with the Uzbek language. In other inflected languages, the participle itself cannot form a sentence unless it is present. In Uzbek, the cut itself forms a sentence and can express an opinion according to the situation: 
CURRENT RESEARCH JOURNAL OF PHILOLOGICAL SCIENCES

(ISSN -2767-3758)

VOLUME 03 ISSUE 01 Pages: 64-72

SJIF IMPACT FACTOR (2021: 5. 823)

OCLC - 1242423883 METADATA IF - 6.925
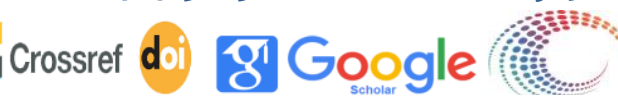

metดpata

5) WorldCat ${ }^{\circ}$ f̂े MENDELEY

Publisher: Master Journals

// HAMMASI. Toshmurod boyvachchani salomatligiga ura! Ura! Ura! (icharlar).

DAVLAT. Jo'ralar. Manuvni ichdim, endi yodimga Lizajon tushdi. O, Lizajon!

HAMMASI. Oh, Lizajon, voh, Lizajon, qaydasan?

NOR. Zolim falak firoqig'a kuydirdi mani; billohki, kelmasa, bo'miydi.

DAVLAT. Bu dodu bedod ila hech nima bo'lmas. Xo'jayinni chaqirarmiz, otam o'Idi bazmi qilarmiz.

NOR. Qo'lingni ber, ey, nomard, topding (qo'lini siqar). Bo'Idi.

// (Behbudi, Padarkush, act 2.)

The morphology of the text is directly related to the comprehensibility and impact of the text on the reader I viewer. It is observed that the author uses more pronouns in this situation in the text of the work:

// DOMULLA (odamlarga qarab). O‘qumoq va mulla bo'Imoq uchun pul kerak, badavlatlarimizni holi bul, bas, bu ketish ila nauzambilloh, dunyo va oxiratga rasvo bo'lurmiz, o'qumoq barcha musulmonga, erkak va yo xotin bo'lsun, farz edi. $U$ qayda qoldi? Oh, voy bizni holimizga!

(Boyga qarab). Boy, man sizga amri ma'ruf etdim va menga shariat bo'yicha lozim bo'lgan ishni bo'ynumdan soqit qildim. Inshoolloh, mo'ylab chiqarib, alifni tayoq demayturgan o'g'lungiz holini ko'rarmiz va o'qutmaganingiz uchun gunohkor bo'lursiz.//

The following example shows that the highlighted words are rhyming words. The frequency with which a phrase is used, in our opinion, depends on the context of the speech and the subject matter. It can be seen that rhymes are used more often in dramatic works than in famous horses. The historical forms of rhymes can be seen in modern dramas. For example, "O'qumoq va mulla bo'Imoq uchun pul kerak, badavlatlarimizni holi bul". Mazkur shakl hozirda qipchoq lahjasida ayrim hududlarda qo'llaniladi.

It is natural that auxiliary phrases are used more often in texts that reflect dialogic speech in forms and functions that are different from today's usage. Here is another text:

//- BOY. So'zingizni jabr va zo'r ila eshittirasizmi? Va yo meni azob bermakkami keldingiz?

ZIYoLI. Yo'q, men asli boshqa ish uchun kelib edim va lekin ilm bahsining ustidan chiqib qoldim. Ushbu sababli muddaoni tabdil qilib, ilm to'g'risidan sizga bayon qilmoqni qasd etdim. Shoyadki, janobingizdek boylar millat bolalarini o‘qutmoqg‘a sa’y qilsalar.

BOY (xalqqa qarab). Koshki, domullo hikoyalari yetmasa edi. Xo‘b, modomiki qo'ymaysiz, ertaroq so'ylab tamom qiling, uyqum kelgan (homuza tortadi), odamlar bolasini o'qut, deydur-a. // (Behbudi, Padarkush, act 1.)

In a dramatic text, the narrator expresses his thoughts and feelings in both monologue and dialogue, and the protagonist uses Arabic terms to increase the effectiveness of certain ideas as he sees new teachings after reading the old school. uses more. For example, the proverb "Seek knowledge from the cradle to the grave" describes the language and speech of its time:

I/- ZIYoLI. Hozir yangi va boshqa bir zamondir. Bu zamonga ilm va hunarsiz xalqni boyligi, yeri va asbobi kundan-kun qo'lidan ketgandek, axloq va obro'yi ham qo'Idan chiqar, hatto, dini ham zaif bo'lur. Buning uchun biz musulmonlarni o'qutmoqg'a sa'y qilmog'imiz lozimdur, vaholanki, dini sharifimiz har nav 
CURRENT RESEARCH JOURNAL OF PHILOLOGICAL SCIENCES

(ISSN -2767-3758)

VOLUME 03 ISSUE 01 Pages: 64-72

SJIF IMPACT FACTOR (2021: 5. 823)

OCLC - 1242423883 METADATA IF - 6.925

Crossref
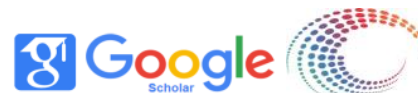

metapata (5) WorldCat I $^{\circ}$ MENDELEY

Publisher: Master Journals

naflik ilm o'qumoqni beshikdan mozorigacha bizlarga farz qilgandir. // (Behbudi, Padarkush, act 1.)

In works of the drama genre, especially in the text of Behbudi's play, prepositions and introductory words are skillfully used to express modal relations:

// Bu hukm - hukmi shariatdir. Biz musulmonlarga, alalxusus, bu zamonda ikki sinf ulamo kerakdur: biri olimi diniy; digari olimi zamoniy. Olimi diniy: imom, xatib, mudarris, muallim, qozi, mufti bo'lub, xaloyiqni diniy va axloqiy va ruhoniy ishlarini boshqarar, bu sinfga kiraturg'on talabalar, avvalo, Turkistonda va Buxoroda ilmiy, diniy va arabiy va bir oz ruscha o'qub, so'ngra Makka, Madina, Misr va Istanbulga borib, ulumi diniyani xatm qilsalar kerak, yoki komil mullo bo'Isunlar (boy mudraydur). Angladingizmi boy?// (Behbudi, Padarkush, act 1.) made effective use of complex conjunctions, mainly because the intellectual spoke to himself and the audience.

From the language units highlighted, it is clear that downloads and entries were actively used in these speech situations.

Due to the lack of definition in the drama, it turned out that the descriptive texts used almost no words for adjectives.

// ZIYoLI. Olimi zamoniy bo'Imoq uchun bolalarni, avvalo, musulmoniy xat va savodini chiqarub, zaruriyati diniya va o'z millatimiz tilini bilaturg'ondan so'ngra hukumatimizni(ng) nizomli maktablariga bermoq kerakdur, ya'ni gimnaziya va shahar maktablarini o'qub tamom qilg‘onlaridan so'ng, Peterburg, Maskov dorilfununlariga yuborib, dokturlik, zakunchilik, injenerlik, sudyalik, ilmi san'at, ilmi iqtisod, ilmi hikmat, muallimlik va boshqa ilmlarni o'qutmoq lozimdir.// (Behbudi, Padarkush, act 1.) As can be seen, in descriptive texts, the author provides information to the addressee through the text. That is why adjectives are less involved.

Let's look at the sociopragmatic features of the text of Behbudi's drama "Padarkush". Here, too, is a descriptive text, so that the reader can get acquainted with the situation as follows:

//... BOY. So'zingizni jabr va zo'r ila eshittirasizmi? Va yo meni azob bermakkami keldingiz?

ZIYoLI. Yo'q, men asli boshqa ish uchun kelib edim va lekin ilm bahsining ustidan chiqib qoldim. Ushbu sababli muddaoni tabdil qilib, ilm to'g'risidan sizga bayon qilmoqni qasd etdim. Shoyadki, janobingizdek boylar millat bolalarini o‘qutmoqg'a sa’y qilsalar.

BOY (xalqqa qarab). Koshki, domullo hikoyalari yetmasa edi. Xo‘b, modomiki qo'ymaysiz, ertaroq so'ylab tamom qiling, uyqum kelgan (homuza tortadi), odamlar bolasini o'qut, deydur-a. // (Behbudi, Padarkush, act 1.) As this text is also descriptive in nature, as mentioned above, adjectives are not active.

The peculiarity of dramas is that they are characterized by non-descriptive words and dialogues. Whenever possible the author should use the right words in the relationship between the speaker and the listener. Just as the artist chooses the colors for the landscape he wants to draw, so the author of the artistic text selects the language units that are similar to this speech situation, this speech act, sorts them out in thought, guesses which word can mean which subtle meaning, and finally puts it in place. Ilaydi. As a result, if the work is successful, the student will be impressed by it, will be able to draw the necessary conclusions, will reflect. The student must be able to imagine in order to think. The dramas provide the same opportunity to the addressee / spectator, where the word reader must be understood in a broad sense, the text reader being a 
CURRENT RESEARCH JOURNAL OF PHILOLOGICAL SCIENCES

(ISSN -2767-3758)

VOLUME 03 ISSUE 01 Pages: 64-72

SJIF IMPACT FACTOR (2021: 5. 823)

OCLC - 1242423883 METADATA IF - 6.925

school student, the book reader in general, the director or the role play can be an acting actor, so it will not be easy for the speaker, the writer, for the work to be successful, it will be necessary to consider all of these addressees, to use language tools that can be understood by them, to create important speech acts.

We also note that words in texts are pragmatic in their use of categories:

//BOY (boshini ko'tarib). Ha, ha, aytabering, qulog'im sizga.

ZIYoLI Rusiya vatanina va davlatina bilfe'l sherik bo'Imoq kerakdir va davlat mansablariga kirmoq lozim. Toki maishati ehtiyoji zamonamiz to'g'risida vatan va millati islomga xizmat qilinsa va ham davlati Rusiya podshohlik mansablariga kirib, musulmonlarga naf yetkurulsa va ham davlati Rusiyaga sherik bo'lunsa, hattoki, shul tariqa o'qugan musulmon bolalarini Farangiston, Amerika va Istanbul dorilfununlariga tarbiya uchun yubormoq kerakdur.// (Behbudi, Padarkush, act 1.) The highlighted words, as mentioned, belong to the noun category. Some of these famous horses are pronounced differently than they are today. From the three examples given, it was found that feature-denominated place names are more likely to be present in informational descriptive texts and to ensure that the information conveyed is valid.

As the author moves from one descriptive purpose to another, the frequency with which word groups participate in speech also changes, and most auxiliary word groups are presented in other morphological forms:

// Hazrat payg'ambarimiz: ilm Xitoyga ham bo'Isa, talab qilingiz, demadilarmi? (Boy uyquda). Bul ishlar bo'Imas, magar pul ila, sizdek katta boylarni himmati ila, chunonchi, Qafkaz, Orenburg va Qozon musulmonlarini boy va ahli g'ayrati ilm yo'liga ko'p pullar sarf etarlar va kambag'al bolalarini o'qutdirarlar (boyga qarab), albatta so'zlarimga tushungansiz, janobi boy. Boy bova, hoy!.// (Behbudi, Padarkush, act 1.) In this text, the activity of the language units that represent the linking relationship is highlighted. The author gives precise information about place names in his language in order to shed more light on the modern worldview of the intelligentsia. It should be noted that the use of nouns in this context has increased the informative nature of the text.

In the drama, we consider the role of language units in the expression of semantic meaning in the process of communication between the speaker and the listener with the following examples:

// Pivaxona manzarasi: boyvachcha ila uch nafar o'Iturarlar.

TANGRIQUL. Bu oqshom, bilmayman, nima uchun ichkilik meni tishlamaydur: Namozi digardan beri bir dyujina shishani bo'shatdim. Dayusni pivosi qulog'imni qizitmadi. To'Idir, ichaylik (Nor qadahlarni to'Idirar).

DAVLAT. Ey, to'taburut Tangriqul. Daming chiqmaydur. Shuncha odam so'zini o'g'irlab o'Iturasan. Erga navbat, sherga navbat. Gap berib o'ltur. Yo bu odamlarni pisand qilmaysanmi? Bizlarni ham yonimizga besh tangalik aqchamiz bor. Jo'ra! Bu mastlik rostlikdir. Qovog'ingni ochib o'Itur.

//(Behbudi, Padarkush, act 2.)

In this text, the speech situation is a conversation between friends, or rather friends. Behbudi uses the language used in folklore. Sentences such as "Daming chiqmaydur - You can't breathe", "Bu mastlik rostlikdir - It's drunken truth”, “Qovog'ingni ochib o'Itur - Open your eyelids and sit down" are, of course, taken from the vernacular. also in Tashmurad's speech, "Bu 
CURRENT RESEARCH JOURNAL OF PHILOLOGICAL SCIENCES

(ISSN -2767-3758)

VOLUME 03 ISSUE 01 Pages: 64-72

SJIF IMPACT FACTOR (2021: 5. 823)

OCLC - 1242423883 METADATA IF - 6.925

Crossref d
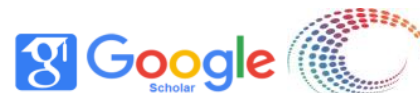

metดpata

5. WorldCat ${ }^{\circ}$ f̂े MENDELEY

Publisher: Master Journals

oqshom, bilmayman, nima uchun ichkilik meni tishlamaydur - Tonight, I don't know why alcohol doesn't bite m" meaning not to bite. This expression is no longer in use today. This expression is very figurative. Biting refers to venomous insects or reptiles, and when they bite, the human body does not feel anything. So in this situation, the person or personality is more important than the action.

Now the drama is changing. At the same time, the issue of social adaptation should not be overlooked in the text of the poems. After all, dialectal words lead to many stylistic and expressive changes. Morphological devices that provide specific information about the speaker indicate the region to which the protagonist belongs:

// TANGRIQUL. Jo'ralar. Sizlardan yashiraturg'on so'zimiz yo'q. To'g'risini desam, manuni ichdim, qulog'im qizig'an, sen Liza deding, endi o'zim shunda bo'Isam-da, hushim Lizaga, to Lizani kelturmasang, mani gapirturolmaysan. Ammo gap kelturganingga, Davlat zo'r!

DAVLAT. G'am yema, muddaong Liza bo'Isa, shul zamon yoningga ko'rarsan, kelmasami? Boshini olarman.

NOR. Boyvachcha! Barishnaga tobingiz bormi?

TOShMUROD. Mayli, odam yuboringlar, bazm qilsun.

TANGRIQUL. Gap, gap ila vaqtni o'tkararsizlar, buyuraturg'on bo'Isanglar, buyuringlar, ertaroq kelsun, kayf qilayluk (Davlat qo'ng'iroq chalar. Artun armani mayxonachi kirar).// (Behbudi, Padarkush, act 2.) The specified language units do not comply with the rules of the Uzbek language. As the events take place in the outskirts of Samarkand, the influence of the Persian pronunciation is felt, as the people living in the city still use the Uzbek language by substituting similar adverbs.

In the text of the work, the people rely on Tashmurad as a sponsor because they know that he is the son of a rich man. In this sense, the text uses linguistic units to express the meaning of life. This is also an important approach for the author. It is also noted that Artun is of Armenian descent. During the conversation, he speaks his Armenian:

DAVLAT. Ha, munda kelturmasdan mozorgami keturarding?

ARTUN. Izvinit surushdim-da.

DAVLAT. Bo'l. Bo'l. Birovni yubor.

ARTUN. Bah, ne vor, bilursin, Liza banga demishki, o'n besh manatsiz banga kishi ko'ndarma. Ha, o'n besh manat-da va faytun pulini-da ver, geyin Nikolayi ko'ndarayum. Liza o'Imasa, boshqasini getirsin, kayfing nechik?

DAVLAT. Avval kelturub, so'ngra pulni olsang bo'Imasmi?

ARTUN. Davlat zo'r! Ban sana demishimki, Liza aqcha olmayincha gelmaz, bana ne? Sen o'zing bilirsanki, u gavur qizi, banim degil.

TANGRIQUL. Artun. Bir oz to‘xta, pul beramiz.

ARTUN. Bosh ustina, hoziram (chiqar. Jo'ralari kayflari uchub, sukut etarlar). // (Behbudi, Padarkush, act 2.)

In the drama, Arthur demonstrates the mentality of his people, and even his business acumen, while remaining true to his mother tongue. The author ui did not speak in this form in vain. 
CURRENT RESEARCH JOURNAL OF PHILOLOGICAL SCIENCES

(ISSN -2767-3758)

VOLUME 03 ISSUE 01 Pages: 64-72

SJIF IMPACT FACTOR (2021: 5. 823)

OCLC - 1242423883 METADATA IF - 6.925

Crossref dol gil Google

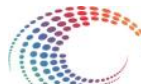
metaparn (5) WorldCat

Publisher: Master Journals

Highlighted language units - entries provide the reader / viewer with reliable information about the nature of Tangrikul:

//DAVLAT. Yo'q, ikkov bas. Ko'rganlar badgumon bo'Imasin. Bukunni ertasi bor.

TANGRIQUL. Albatta. Bormay nima bo'lubdur (Davlat to'pponchasini boyvachchaga berar. Nor etik sog'idan pichoqni olib, Tangriqulga berar. Alar ehtiyot qilib turarlar).

DAVLAT. (ikkisiga qarab). Yo‘l bo‘lsin, botirlar?

TANGRIQUL. Olgani (Davlat Tangriqulni bir chetga olib, ishorat va xufiya ma'lumot va amr berar).

NOR. Omin, olloh... (Hammasi) Ollohu akbar. (Davlat fotiha berar). (Behbudi, Padarkush, act 2.)

\section{CONCLUSION}

Due to the dramatic text, more entries and exclamations are actively used along with the horses. In general, different morphological units are found to be active in different places in the drama, depending on the situation of the speech. In this way, to facilitate research on the frequency of use of phrases, it is necessary to know which phrases are more prevalent in which speech situation, as well as the linguistic features of dramatic speech, the grammatical meanings that underlie speech adaptation. conclusions can be drawn.

\section{REFERENCES}

1. Hakimov M. Pragmatic interpretation of the text in Uzbek language: Doctor of Philology dissertation. - Toshkent, 2011. - p. 94.
2. M. Kurbanova Pragmalinguistic analysis of types of children's speech acts. Foreign philology. Samarkand. 2016. Issue 4. - pp. 96-97.

3. Tursunov $U$. et al. Modern Uzbek literary language: A textbook for students of the Faculty of Philology of the University. U. Tursunov, A. Mukhtorov, Sh. Rahmatullaev; Revised and supplemented edition. - T .: Uzbekistan, 1992. - p. 399.

4. Behbudiy M. Selected works - T .: Spirituality, 1999. - p. 69 .

5. N.I. Khursanov. Linguistic Classifications Related to Discourse and Its Classifications. October 2021 Theoretical \& Applied Science 102(10):825-829 DOI: 10.15863/TAS.2021.10.102.92

6. N.I. Khursanov On the theoretical and practical foundations of language corpora. January 2021Asian Journal of Multidimensional Research (AJMR) 10(9):311-318 DOI: 10.5958/22784853.2021 .00675 .3

7. L.R. Raupova, G.Q. Safarova. Euphemism-As a Linguistic Unit Expressing National-Mental Identity//Current Research Journal of Philological Sciences (2767-3758). - 2021. - T. 2. - №. 10. - C. $125-133$.

8. L.R. Raupova, \& Sh, Sultonova. (2021). Scientific Basis of Compiling a Dictionary of Grammatical Terms. Current Research Journal of Philological Sciences (2767-3758), 2(10), 116-124. 


\section{CURRENT RESEARCH JOURNAL OF PHILOLOGICAL SCIENCES}

(ISSN -2767-3758)

VOLUME 03 ISSUE 01 Pages: 64-72

SJIF IMPACT FACTOR (2021: 5. 823)

OCLC - 1242423883 METADATA IF - 6.925
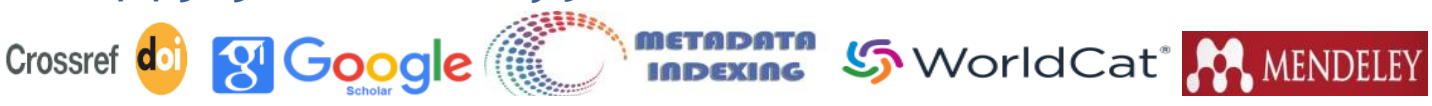

Publisher: Master Journals

9. N.I. Khursanov. (2021) Linguistic Classifications Related to Discourse and Its Classifications. October 2021. Theoretical \& Applied Science 102(10):825-829. DOI: 10.15863/TAS.2021.10.102.92

10. Ismatullaeva, N. R. (2020). Methods Of Elimination Of Lexical Gaps In Translation (on example of Chinese and Uzbek languages). Scientific Bulletin of Namangan State University, 2(10), 305-314. 